\title{
Pengaruh Religiusitas, Pengetahuan, Perspesi, Pendapatan, dan Media Infromasi terhadap Minat Wakaf Uang Masyarakat Kota Bandung
}

\author{
Amin Abdul Rohman* \\ Prodi Ekonomi Pembangunan, Fakultas Ekonomi dan Bisnis, \\ Universitas Islam Bandung, Indonesia. \\ *aminabdulrohman77@gmail.com
}

\begin{abstract}
Waqf is one of the instruments of Islamic philanthropy that has long been solving problems for Muslims ranging from problems to welfare problems. Waqf is also worship with a double effect. Apart from being a worship to Allah SWT, waqf is also a social worship. Endowments continued to be developed until in 2004 the government formulated Law no. 41 of 2004 concerning waqf, including the division of waqf types, namely movable waqf and immovable waqf, including cash waqf. The potential for cash waqf is currently very high but the revenue has not yet been able to reach the target potential. Therefore, in order to make a strategy to increase interest in waqf in wanting cash waqf from the community side, it is necessary to study the interest in cash waqf in a case study in the city of Bandung. The research method used is descriptive quantitative research using field research and primary data from a questionnaire as many as 100 Muslim community members of Bandung City, which were taken by convenience sampling. The results showed that people in the city of Bandung have a high interest in cash waqf with at least doing cash waqf once in their lifetime. Variables that affect the interest in cash waqf in the city of Bandung are influenced by the variables of religiosity, income and perception. While the knowledge and media information variables have no effect on the interest in cash waqf of the people of Bandung City. Among these factors. The dominant factors influencing the interest of the people of Bandung City to donate money are income and perception factors.
\end{abstract}

Keywords: Religiosity, Knowledge, Perception, Income, Perception, Information Media, Cash Waqf, Interests, Bandung City Society

\begin{abstract}
Abstrak. Wakaf merupakan salah satu instrumen filantropi Islam yang sejak lama telah menjadi pemecahan masalah bagi umat Islam mulai dari masalah kemiskinan hingga masalah kesejahteraan. Wakaf juga merupakan ibadah dengan efek ganda. Selain merupakan suatu ibadah kepada Allah Swt., wakaf juga merupakan ibadah yang bersifat sosial. Wakaf terus dilakukan pengembangannya hingga pada tahun 2004 pemerintah merumuskan Undang-undang No. 41 Tahun 2004 tentang wakaf termasuk didalamnya terdapat pembagian jenis wakaf yaitu wakaf bergerak dan wakaf tidak bergerak yang diantaranya adalah wakaf uang. Potensi Wakaf uang saat ini sangat tinggi akan tetapi penerimaannya sampai sekarang belum bisa mencapai target potensi. Oleh karena itu, dalam rangka untuk membuat strategi meningkatkan minat wakif dalam berkeinginan wakaf uang dari sisi masyarakat, maka perlu dikaji minat wakaf uang studi kasus di Kota Bandung. Metode penelitian yang digunakan yaitu penelitian deskriptif kuantitatif dengan menggunakan jenis penelitian survey lapangan dan data primer dari kuesioner sebanyak 100 orang masyarakat muslim Kota Bandung yang diambil secara convenience sampling. Hasil penelitian menunjukan bahwa masyarakat di Kota Bandung memiliki minat yang tinggi dalam berwakaf uang dengan minimal melakukan wakaf uang sekali dalam seumur hidupnya. Variabel yang mempengaruhi minat wakaf uang di Kota Bandung dipengaruhi adalah variabel religiusitas, pendapatan dan persepsi. Sedangkan variabel pengetahuan dan media informasi tidak berpengaruh terhadap minat berwakaf uang masyarakat Kota Bandung. Diantara faktor-faktor tersebut. Faktorfaktor yang dominan mempengaruhi minat masyarakat Kota Bandung berwakaf uang yaitu faktor pendapatan dan perspesi.
\end{abstract}

Kata Kunci: Religiusitas, Pengetahuan, Persepsi, Pendapatan, Persepsi, Media Informasi, Wakaf Uang, Minat, Masyarakat Kota Bandung 


\section{A. Pendahuluan}

Wakaf uang merupakan bagian dari salah satu wakaf bergerak dalam istilah lain disebut cash waqf/ waqf al-qund. Wakaf uang dilakukan oleh individu, kelompok, Lembaga atau badan hukum dalam bentuk uang tunai, termasuk juga surat-surat berharga. Wakaf Uang disebutkan dalam Undang-undnag Nomor 41 Tahun 2004 sebagai penyerahan secara tunai sejumlah uang wakaf dalam bentuk mata uang rupiah yang dilakukan oleh wakif kepada nazir melalui lembaga keuangan syariah penerima wakaf uang (LKS-PWU) yang ditunjuk oleh Menteri Agama atas saran dan pertimbangan Badan Wakaf Indonesia (BWI). Perilaku wakaf uang harus dimulai dengan minat yang timbul dalam diri seseorang melalui faktor-faktor yang mempengaruhi minat yaitu religiusitas, pengetahuan, perspesi, pendapatan, religiusitas, dan media informasi.

Menurut Jalaludin (1) menyatakan bahwa, "Religiusitas adalah suatu keadaan yang ada dalam diri seseorang yang mendorongnya untuk bertingkah laku sesuai dengan kadar ketaatannya terhadap agama yang sumbernya secara langsung atau tidak langsung kepada Nash".

Menurut Jamarah \& Zaini (2) menyatakan bahwa, "Pengetahuan adalah sebuah proses perubahan sikap dan tatalaku seseorang atau kelompok dan juga usaha manusia melalui upaya pengajaran dan pelatihan, maka jelas dapat kita ambil benang merahnya bahwa sebuah visi Pengetahuan yaitu untuk mencerdaskan manusia".

Menurut Sarwono (3) menyatakan bahwa, "Persepsi adalah suatu proses pengindraan manusia dengan mengumpulkan berbagai informasi mengenai apa yang ada disekitar kita sehingga timbul dalam dirinya suatu pemahaman mengenai hal tertentu".

Menurut Reksopreyitno (4) menyatakan bahwa, "Pendapatan adalah besaran penerimaan yang diberi nilai dengan mata uang yang dihasilkan oleh seseorang atau suatu negara dalam rentan waktu tertentu".

Menurut Sasmita (5) menyatakan bahwa, "Media Informasi adalah alat untuk mengumpulkan dan menyusun kembali sebuah informasi sehingga menjadi bahan yang bermanfaat bagi penerima informasi. Melalui media infromasi masyarakat dapat mengetahui informasi yang ada serta dapat berinteraksi satu sama lain".

Menurut Kamus Besar Bahasa Indonesia (6), Minat merupakan condongnya hati yang besar terhadap sesuatu atau dapat pula disebut dengan gairah atau keinginan. Minat adalah rasa suka yang timbul atau rasa ketertarikan pada hal atau kegiatan tertentu tanpa adanya paksaan. Minat dasarnya adalah suatu keterhubungan yang timbul antara diri sendiri dengan luar diri, semakin kuat hubungannya maka semakin besar minatnya.

Berdasarkan agama dan hukum normatif, wakaf merupakan kegiatan yang sangat bermanfaat baik itu bagi hubungan dirinya dengan Allah Swt. maupun hubungan dirinya dengan orang lain. Akan tetapi potensi wakaf uang baik secara nasional maupun daerah khususnya di Kota Bandung belum dapat terealisasikan. Sehingga apabila seorang muslim memiliki faktor diantaranya pendapatan, Pendidikan, agama, media informasi, dan persepsi yang baik terhadap prilaku berwakaf uang maka dalam dirinya akan timbul minat untuk berwakaf uang. Dan apabila minat tersebut dilakukan terus menerus kemudian menjadi perilaku atau kebiasaan dalam hidupnya, maka hal tersebut akan berpengaruh terhadap penghimpunan wakaf sesuai dengan potensi yang diharapkan.

Berdasarkan latar belakang yang telah diuraikan, maka perumusan masalah dalam penelitian ini sebagai berikut:

1. Bagaimana minat wakaf uang masyarakat Kota Bandung?

2. Bagaimana pengaruh religiusitas, pengetahuan, persepsi, pendapatan, dan media informasi terhadap minat wakaf uang masyarakat Kota Bandung?

3. Faktor apa yang paling dominan mempengaruhi minat wakaf masyarakat Kota Bandung.

Selanjutnya, Berdasarkan identifikasi masalah yang terkait dengan judul penelitian ini, maka tujuan penelitian yang dapat diuraikan: 
1. Untuk mengetahui minat wakaf uang masyarakat Kota Bandung.

2. Untuk mengetahui pengaruh religiusitas, pengetahuan, persepsi, pendapatan, dan media informasi terhadap minat wakaf uang masyarakat Kota Bandung.

3. Faktor apa yang paling dominan mempengaruhi minat wakaf masyarakat Kota Bandung.

\section{B. Metodologi Penelitian}

Peneliti menggunakan metode teknik analisis deskriptif dengan menggunakan pendekatan kuantitatif. Populasi yang dipilih dalam penelitian ini adalah masyarakat muslim Kota Bandung berjumlah 2.619 .094 orang.

Dengan teknik pengambilan sampel yaitu Convenience Sampling diperoleh jumlah sampel penelitian sebanyak 100 orang. Teknik pengumpulan data yang digunakan dalam penelitian ini adalah kuesioner, studi pustaka. Adapun teknik analisis data yang digunakan dalam penelitian ini adalah teknis analisis deskriptif dan teknik analisis regresi linier berganda.

\section{Hasil Penelitian dan Pembahasan}

Deskriptif Profil Jenis Kelamin, Usia, Pekerjaan, Pendidikan Terakhir, dan Jumlah pendapatan Perbulan Responden.

Berikut adalah penelitian mengenai deskriptif profil jenis kelamin, usia, pekerjaan, pendidikan terakhir, dan jumlah pendapatan perbulan responden. Hasil pengujian dijelaskan pada tabel berikut.

Tabel 1. Profil Jenis Kelamin

\begin{tabular}{|c|c|}
\hline Kriteria & Persentase \\
\hline Laki-Laki & $48,1 \%$ \\
\hline Perempuan & $51,9 \%$ \\
\hline
\end{tabular}

Sumber: Hasil Pengolahan Data Penelitian (2021)

Berdasarkan table 1. Respon masyarakat Bandung terhadap penelitian ini dilihat dari jenis kelamin yaitu perempuan sebesar 51,9\% dan laki-laki sebesar 48,1\%. Dapat disimpulkan bahwa responden dalam penelitian ini hampir seimbang antara responden laki-laki dan perempuan, ini terjadi disebabkan oleh pengambilan responden secara acak melalui formulir online menimbulkan beberapa peluang selisih jumlah responden antara laki-laki dan perempuan. Pada penelitian kali ini peluang selisih jumlah responden yang muncul antara laki-laki dan perempuan adalah hampir mendekati seimbang.

Tabel 2. Profil Usia

\begin{tabular}{|c|c|}
\hline Kriteria & Persentase \\
\hline Di bawah 19,99 tahun & $6,5 \%$ \\
\hline 20 tahun-29,90 tahun & $72,2 \%$ \\
\hline 30 tahun-39,99 tahun & $12 \%$ \\
\hline Diatas 40 tahun & $10,2 \%$ \\
\hline
\end{tabular}

Sumber: Hasil Pengolahan Data Penelitian (2021)

Berdasarkan table 2. Responden yang mendominasi dalam penelitian ini dapat disebut sebagai masyarakat dengan usia produktif. Diketahui banyak responden yang termasuk usia produktif yaitu usia kisaran umur 15 tahun sampai 64 tahun. Dalam hal ini responden berdasarkan usia yang mendominasi dalam penelitian ini telah sesuai target. Karena usia produktif sangat berpotensi untuk timbul rasa minat terhadap wakaf uang karena usia produktif apabila dilihat dari segi penghasilan dan pengetahuan telah mumpuni untuk berwakaf uang. 
Tabel 3. Pekerjaan

\begin{tabular}{|c|c|}
\hline Kriteria & Persentase \\
\hline PNS/TNI/Polri & $10,2 \%$ \\
\hline Wiraswasta & $4,6 \%$ \\
\hline Ibu Rumah Tangga & $5,5 \%$ \\
\hline Pegawai Swasta & $20,4 \%$ \\
\hline Pelajar/Mahasiswa & $38 \%$ \\
\hline lainnya & $21,3 \%$ \\
\hline
\end{tabular}

Sumber: Hasil Pengolahan Data Penelitian (2021)

Berdasarkan table 3. Banyaknya responden masyarakat terhadap penelitian yang didominasi mahasiswa dikarenakan dalam penyebaran kuesioner ini lebih banyak dibagikan di grup whatsapp kampus dan grup mahasiswa, kemudian literasi mengenai wakaf uang lebih bnyak dipahami oleh mahasiswa yang dijelaskan pada matakuliah di kampus dari pada pekerja wirausaha atau pekerja yang mana masih terbatasnya informasi mengenai wakaf uang. Sehingga responden terbanyak dalam penelitian ini yaitu kalangan mahasiswa.

Tabel 4. Pendidikan Terahir

\begin{tabular}{|c|c|}
\hline Kriteria & Persentase \\
\hline SD & $0,9 \%$ \\
\hline SMP/Sederajat & $0,9 \%$ \\
\hline SMA/Sederajat & $32,4 \%$ \\
\hline Diploma I-Diploma III & $4,6 \%$ \\
\hline S1-S3 & $61,1 \%$ \\
\hline
\end{tabular}

Sumber: Hasil Pengolahan Data Penelitian (2021)

Berdasarkan table 4. Responden dengan latar pendidikan terakhir terbanyak yaitu responden dengan pendidikan dengan gelar Strata sebesar $61,1 \%$ atau sebanyak 66 orang. Responden yang lainnya yaitu pendidikan terkahir dengan gelar diploma sebesar 4,6\% atau sebanyak 5 orang, SMA sederajat sebesar 32,4\% atau sebanyak 35 orang, SMP sederajat sebesar $0,9 \%$ atau sebanyak 1 orang, dan SD sebesar $0,9 \%$ atau sebanyak 1 orang. Menurut data responden diatas dapat disimpulkan bahwa hampir seluruh responden yang mengisi kuesioner tersebut dapat dikatakan sebagai responden yang melek terhadap pengetahuan. Diharapakan pengetahuan tentang wakaf telah didapatkan di pendidikan terakhirnya.

Tabel 5. Jumlah Pendapatan Perbulan

\begin{tabular}{|c|c|}
\hline Kriteria & Persentase \\
\hline Di bawah Rp. 999.999,- & $41,7 \%$ \\
\hline Rp. 1.000.000,- s/d Rp. 4.999.999,- & $38,9 \%$ \\
\hline Rp. 5.000.000,- s/d Rp. 9.999.999,- & $14,9 \%$ \\
\hline Di atas Rp. 10.000.000,- & $4,6 \%$ \\
\hline
\end{tabular}

Sumber: Hasil Pengolahan Data Penelitian (2021)

Berdasarkan table 5. dapat disimpulkan bahwa responden yang paling banyak berpasrtisipasi dalam penelitian ini adalah mereka yang berpenghasilan dibawah Rp. 999.999 yaitu sebesar $41,7 \%$ atau sebanyak 45 orang. Ini sangat berhubungan sekali dengan data mengenai pekerjaan sebelumnya. Pekerjaan yang paling mendominasi adalah kalangan mahasiswa yang masih banyak mungkin diantaranya belum berpenghasilan atau masih tanggungan dari orang tua.. 
Deskripsi Tanggapan Responden Terhadap Variabel Minat (Y), Religiusitas (X1), Pengetahuan (X2), Persepsi (X3), Pendapatan (X4), dan Media Informasi (X5)

Berikut adalah penelitian mengenai deskripsi tanggapan responden terhadap variabel minat (Y), Religiusitas (X1), Pengetahuan (X2), Persepsi (X3), Pendapatan (X4), dan Media Informasi (X5). Hasil pengujian dijelaskan pada tabel 2.

Tabel 6. Deskripsi Tanggapan Responden

\begin{tabular}{|c|l|c|c|c|}
\hline No. & \multicolumn{1}{|c|}{ Variabel } & Jumlah Pernyataan & Rata-rata Jawaban & Kategori \\
\hline 1. & Minat & 3 & 4,22 & Setuju \\
\hline 2. & Religiusitas & 8 & 4,43 & Sangat Setuju \\
\hline 3. & Pengetahuan & 6 & 3,91 & Setuju \\
\hline 4. & Persepsi & 5 & 4,30 & Setuju \\
\hline 5. & Pendapatan & 6 & 4,0 & Setuju \\
\hline 6. & Media Informasi & 12 & 3,66 & Setuju \\
\hline
\end{tabular}

Sumber: Data Output dari Microsoft Excel (2021)

Berdasarkan tabel 6 rata-rata jawaban varabel minat 4,22 kategorinya setuju terhadap pernyataan varibel minat. Hasil menunjukkan bahwa pada umunya masyarakat Kota Bandung banyak yang berminat melakukan wakaf uang dengan minimal melakukan wakaf uang sekali dalam seumur hidupnya bahkan ada yang sampai setahun sekali. Hasil ini terkait dengan data profil responden pendidikan, responden berminat karena mempunyai pengetahuan yang didapatkan dari pendidikan terakhirnya, orang tidak mengerti apapun dan tidak didukung dengan pendidikannya tidak mungkin muncul rasa minat sangat sesuai dengan pernyataan bahwa minat timbul mulai dari munculnya rasa senang tanpa adanya suatu paksaan kemudian diikuti juga dengan respon positif berupa intensitas melakukan wakaf uang yang tidak hanya dilakukan sekali dalam seumur hidupnya.

Berdasarkan tabel 6, rata-rata jawaban varabel religiusitas 4,43 kategorinya sangat setuju terhadap pernyataan varibel religiusitas. Hasil menunjukkan bahwa pada umunya masyarakat Kota Bandung berminat berwakaf uang yang didasarkan pada keyakinan terhadap hadis Rasulullah. Saw "Apabila manusia itu meninggal dunia maka terputuslah segala amalnya kecuali tiga: yaitu sedekah jariyah, ilmu yang bermanfaat atau anak soleh yang mendoakan kepadanya" (HR. Muslim). dan keyakinan terhadap Al-Qur'an surah Ali Imran ayat 92 yang berbunyi: "Kamu tidak akan memperoleh kebajikan, sebelum kamu menginfakkan sebagian harta yang kamu cintai. Dan apapun yang kamu infakkan, tentang hal itu sungguh, Allah maha mengetahui".

Setelah Keyakinan pada sumber agama Islam tersebut kuat, maka responden selanjutnya akan melaksanakan praktik keagamaan, praktik keagamaan disini berupa perwujudan kegiatan yang dilandaskan dengan sumber nash yang ada, dalam hal ini adalah melakukan praktik wakaf uang yang terbukti sebagai amal jariyah dan telah dicontohkan berdasarkan tuntunan sunnah Rasululah Saw. Praktik keagamaan yang dilandaskan pada sumber agama yang jelas tentu menjadikan responden tidak akan ragu lagi untuk berminat terhadap kegiatan wakaf uang.

Kemudian dari dimensi praktik keagamaan yang jelas dan sesuai tuntutan, maka tahap selanjutnya masuk kepada dimensi pengalaman. Orang yang telah berminat tidak mungkin hanya melakukan sekali dalam seumur hidupnya, maka kegiatan berwakaf uang akan diikuti pengamalan hati yang ikhlas dan menyerahkan semua balasan dan pahala wakaf uang kepada Allah Swt. Indikator selanjutnya yang tidak kalah penting yaitu dimensi pengetahuan dan pengamalan agama, kedua indikator ini pada dasarnya saling berhubungan. Pengetahuan agama yang kuat, tentu tidak akan membuat responden ragu dengan minat berwakaf uang maka setelah pengetahuan agamanya memadai, akhirnya responden akan menjadikan wakaf uang sebagai amalan keagamaanya.

Berdasarkan tabel 6, rata-rata jawaban variable pengetahuan 3,91 kategorinya setuju terhadap pernyataan varibel pengetahuan. Hasil menunjukkan bahwa pada umunya masyarakat 
Kota Bandung berminat berwakaf uang yang didasarkan pada wawasan pengetahuan mulai dari definisi, jenis, hukum, rukun, syarat dan manfaat wakaf uang. Ketika responden belum menguasai wawasan pengetahuan tentang wakaf uang tersebut, maka akan sulit untuk membentuk sikap dan perilaku yang memungkinkan munculnya minat berwakaf uang. Wawasan pengetahuan harus dimulai dengan proses belajar sehingga akan muncul dalam diri responden keterampilan dan tercipta pemikiran untuk melakukan wakaf uang dengan metode yang paling efektif dan efisien. Hasil tanggapan responden ini juga menggambarkan masih banyak responden yang mengira bahwa dengan wawasan yang tidak terlalu mendalam mengenai wakaf uang dapat mendorongnya berminat wakaf uang, padahal sebenarnya wakaf uang adalah amal ibadah yang harus diketahui terlebih dahulu dasarnya baru kemudian pengimplementasiannya. Hal ini harus dilakukan supaya menghindari amal ibadah yang tidak didasari pengetahuan tentang ilmunya.

Berdasarkan tabel 6, rata-rata jawaban varabel persepsi 4,30 kategorinya setuju terhadap pernyataan varibel persepsi. Hasil menunjukkan bahwa pada umunya masyarakat Kota Bandung berminat berwakaf uang yang didasarkan pada tanggapan masyarakat yang menyatakan wakaf uang dapat membantu pembangunan perekonomian. Pembangunan perekonomian ditandai dengan menurunnya tingkat kemiskinan dan ketimpangan sosial, responden berharap wakaf uang dapat menanggulanginya. Tanggapan responden terhadap wakaf uang ini harus didukung dengan kinerja lembaga wakaf uang itu sendiri. Agar responden dapat menilai bahwa wakaf uang dapat mempermudah masyarakat muslim dalam melakukan wakaf. Selain itu juga responden menilai bahwa lembaga wakaf uang telah mengelola dana wakafnya dengan baik dan produktif untuk kemaslahatan bersama.

Berdasarkan tabel 6, rata-rata jawaban varabel pendapatan 4,0 kategorinya setuju terhadap pernyataan variable pendapatan. Hasil menunjukkan bahwa pada umunya masyarakat Kota Bandung berminat berwakaf uang yang didasarkan tingkat pendapatan seseorang. Masih banyak sebagian masyarakat di Kota Bandung yang belum bisa mengalokasikan sebagian harta untuk berwakaf uang, penyebabnya mungkin karena kurang adanya pengetahuan mengenai wakaf uang atau tingkat religiusitas yang dimiliki oleh masyarakat Kota Bandung masih rendah sehingga masih kurang adanya semangat untuk berwakaf uang. Selain itu juga, pendapatan yang didapatkan bagi calon pemberi wakaf uang harus dari usaha yang halal, halal menurut syariat agama. Baik dilihat dari sisi bentuk usahanya maupun barang atau jasa yang dijadikan usahanya. Harta wakaf akan terus dimanfaatkan sampai habis, hancur, atau musnahnya barang wakaf tersebut.

Ketika harta yang diwakafkan bukan dari usaha yang halal maka ditakutkan bukan pahala dan keberkahan yang didapatkan dari barang tersebut, melainkan kemudharatan dan ketidakmanfaatkan yang didapatkan. Semua responden mengakui usaha yang dijalaninya merupakan usaha yang halal. Seperti dalam firman Allah Swt. dalam Q.S Ali Imran ayat 92 yang berbunyi: "Kamu sekali-kali tidak akan memperoleh kebajikan (yang sempurna) sebelum kamu menginfakkan sebagian harta yang kamu cintai. Apa pun yang kamu infakkan, sesungguhnya Allah Maha Mengetahui tentangnya". Setelah harta wakaf uang disalurkan dari pendapatan yang memdai dan diperoleh dari usaha yang halal, maka selanjutnya hartanya tentu bisa diwakafkan, karena harta halal akan menambah keberkahan dalam melakukan wakaf uang. Sebelum harta akan diwakafkan sebaiknya harus melihat terlebih dahulu besaran penghasilan yang didapatkan oleh responden. Karena bagaimanapun kebutuhan pribadi berupa sandang,pangan, dan papan yang harus didahulukan, baru setelah semua tercukupi dan besaran penghasilan memiliki kelebihan, maka sudah saatnya harta tersebut dapat disedekahkan terutama dalam berbentuk wakaf uang.

Berdasarkan tabel 6, rata-rata jawaban varabel media informasi 3,66 kategorinya setuju terhadap pernyataan varibel media informasi. Hasil menunjukkan bahwa pada umunya masyarakat Kota Bandung berminat berwakaf uang yang didasarkan pada keyakinan terhadap hadis Rasulullah. Saw "Apabila manusia itu meninggal dunia maka terputuslah segala amalnya kecuali tiga: yaitu sedekah jariyah, ilmu yang bermanfaat atau anak soleh yang mendoakan kepadanya" (HR. Muslim). dan keyakinan terhadap Al-Qur'an surah Ali Imran ayat 92 yang berbunyi: "Kamu tidak akan memperoleh kebajikan, sebelum kamu menginfakkan sebagian 
harta yang kamu cintai. Dan apapun yang kamu infakkan, tentang hal itu sungguh, Allah maha mengetahui". Berminat berwakaf uang ditentunkan dengan nilai dari informasi yang disampaikan oleh media kepada responden. Responden menilai bahwa media informasi mengenai wakaf uang sangat penting dan harus disampaikan secara luas agar calon wakif wakaf uang benar-benar faham dan mengenal secara umum mengenai wakaf uang. Pentingnya media informasi mengenai wakaf uang ini harus diikuti dengan keakuratan data dan harus sesuai fakta yang ada, baik itu dilihat dari isi informasi wakaf uang itu sendiri maupun keakuratan dan ketepatan penerima informasi wakaf uang. Melihat data yang ada, responden menilai bahwa media informasi mengenai wakaf uang sudah sesuai dengan fakta yang ada dan penerima informasinya sudah tepat sasaran dengan frekuensi responden setuju dengan pernyataan ini sebesar 72 responden.

Selain itu juga, responden memberi tanggapan kepada beberapa jenis media informasi yang mungkin pemerintah ataupun lembaga pengelola wakaf memanfaatkan media informasi tersebut. Media informasi tersebut diantaranya yaitu ceramah di masjid, pengajian di majelis talim, siaran televisi, seminar-seminar, media cetak seperti buku dan surat kabar, jejaring sosial di internet, sosialisasi oleh nazhir wakaf, dan infromasi yang sedang banyak dibicarakan yaitu mengenai gerakan wakaf uang oleh presiden RI. Berdasarkan beberapa jenis media informasi tersebut, hasil data responden menunjukkan bahwa secara umum masih banyak masyarakat Kota Bandung yang belum mendapatkan informasi mengenai Wakaf uang. Hasil data menunjukkan bahwa jenis media informasi wakaf uang yang paling banyak disetujui responden dalam mendapatkan infomasi yaitu dari jejaring sosial di internet seperti Facebook, Instagram, Whatsapp, dan yang lainnya sebesar 47 responden. Sedangkan jensi media informasi lainnya sangat minim informasi mengenai wakaf uang. Terutama infomrasio mengenai Gerakan wakaf uang yang mana respoden masih banyak yang belum mengetahuinya dengan jumlah responden sebesar 32 saja yang setuju.

Hubungan Antara Religiusitas (X1), Pengetahuan (X2), Persepsi (X3), Pendapatan (X4), dan Media Informasi (X5) dengan Minat Wakaf Uang (Y)

Berikut adalah penelitian mengenai hubungan Antara Religiusitas, Pengetahuan, Persepsi, Pendapatan , dan Media Informasi dengan Minat Wakaf Uang. Hasil pengujian dijelaskan pada tabel 7.

Tabel 7. Hubungan Antara Religiusitas (X1), Pengetahuan (X2), Persepsi (X3), Pendapatan (X4), dan Media Informasi (X5) dengan Minat Wakaf Uang (Y)

\begin{tabular}{|c|c|c|c|c|c|c|}
\hline Variabel & Sig. & Prob. & $\mathrm{t}_{\text {hitung }}$ & $\mathrm{T}_{\text {tabel }}$ & Keputusan & Keterangan \\
\hline Religiusitas & 0,085 & 0,10 & 1,742 & 1,660 & $\mathrm{H}_{0}$ ditolak & Berpengaruh \\
\hline Pengetahuan & 0,701 & 0,10 & 0,385 & 1,660 & $\mathrm{H}_{0}$ diterima & Tidak Berpengaruh \\
\hline Persepsi & 0,006 & 0,10 & 2,827 & 1,660 & $\mathrm{H}_{0}$ ditolak & Berpengaruh \\
\hline Pendapatan & 0.001 & 0,10 & 3,517 & 1,660 & $\mathrm{H}_{0}$ ditolak & Berpengaruh \\
\hline $\begin{array}{c}\text { Media } \\
\text { Informasi }\end{array}$ & 0,107 & 0,10 & 1,628 & 1,660 & $\mathrm{H}_{0}$ diterima & Tidak Berpengaruh \\
\hline
\end{tabular}

Sumber: Data Output dari SPSS (2021)

Berdasarkan Tabel 7. menunjukkan Nilai thitung variabel religiusitas (X1) sebesar 1,742 yang mana lebih besar dari $t_{\text {tabel }} 1,660$ sehingga $t_{\text {hitung }}$ lebih besar dari $t_{\text {tabel }}(1,742>1,660)$ dengan probabilitas signifikansi $0,085<0,10$. Maha $\mathrm{H}_{1}$ diterima $\mathrm{H}_{0}$ ditolak, artinya bahwa variabel religiusitas secara parsial berpengaruh signifikan terhadap minat wakaf uang masyarakat Kota Bandung.

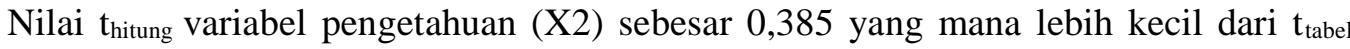
1,660 sehingga $t_{\text {hitung }}$ lebih kecil dari $t_{\text {tabel }}(0,385<1,660)$ dengan probabilitas signifikansi 0,701 $>0,10$. Maha $\mathrm{H}_{0}$ diterima $\mathrm{H}_{1}$ ditolak, artinya bahwa variabel pengetahuan secara parsial tidak berpengaruh signifikan terhadap minat wakaf uang masyarakat Kota Bandung.

Nilai $t_{\text {hitung }}$ variabel persepsi (X3) sebesar 2,827 yang mana lebih besar dari $t_{\text {tabel }} 1,660$ sehingga $t_{\text {hitung }}$ lebih besar dari $t_{\text {tabel }}(2,827>1,660)$ dengan probabilitas signifikansi $0,006<$ 
0,10. Maha $\mathrm{H}_{1}$ diterima $\mathrm{H}_{0}$ ditolak, artinya bahwa variabel persepsi secara parsial berpengaruh signifikan terhadap minat wakaf uang masyarakat Kota Bandung.

Nilai $t_{\text {hitung }}$ variabel pendapatan (X4) sebesar 3,517 yang mana lebih besar dari $t_{\text {tabel }} 1,660$ sehingga $t_{\text {hitung }}$ lebih besar dari $t_{\text {tabel }}(3,517>1,660)$ dengan probabilitas signifikansi $0,001<$ 0,10. Maha $\mathrm{H}_{1}$ diterima $\mathrm{H}_{0}$ ditolak, artinya bahwa variabel persepsi secara parsial berpengaruh signifikan terhadap minat wakaf uang masyarakat Kota Bandung.

Nilai $t_{\text {hitung }}$ variabel media informasi (X5) sebesar 0,144 yang mana lebih kecil dari tabel 1,660 sehingga $t_{\text {hitung }}$ lebih kecil dari $t_{\text {tabel }}(0,385<1,660)$ dengan probabilitas signifikansi 0,107 $>0,10$. Maha $\mathrm{H}_{0}$ diterima $\mathrm{H}_{1}$ ditolak, artinya bahwa variabel media informasi secara parsial tidak berpengaruh signifikan terhadap minat wakaf uang masyarakat Kota Bandung.

\section{Variabel Paling Dominan Mempengaruhi Minat Wakaf Uang (Y)}

Berikut adalah penelitian mengenai variabel paling dominan mempengaruhi minat wakaf uang (Y). Hasil pengujian dijelaskan pada tabel 8.

Tabel 8. Variabel Paling Dominan Mempengaruhi Minat Wakaf Uang (Y)

\begin{tabular}{|c|c|c|}
\hline Variabel & Nilai Koefisien & Keterangan \\
\hline Religiusitas & 0,105 & Berpengaruh \\
\hline Pengetahuan & 0,029 & Tidak Berpengaruh \\
\hline Persepsi & 0,242 & Dominan Berpengaruh \\
\hline Pendapatan & 0,240 & Dominan Berpengaruh \\
\hline Media Informasi & 0.075 & Tidak Berpengaruh \\
\hline
\end{tabular}

Sumber: Data Output dari SPSS (2021)

Berdasarkan Tabel 8. variabel yang memiliki pengaruh terhadap minat wakaf uang masyarakat Kota Bandung ada 3 variabel, yaitu variabel religiusitas, persepsi dan variabel pendapatan. Diantara 3 variabel tersebut, variabel pendapatan dan persepsi merupakan faktor yang dominan berpengaruh terhadap minat wakaf uang masyarakat Kota Bandung. Dengan hasil koefisien paling tinggi yaitu masing-masing sebesar 0,240 dan 0,242.

\section{Kesimpulan}

Berdasarkan pembahasan dalam penelitian ini, peneliti menyimpulkan beberapa hasil penelitian sebagai berikut:

1. Sebanyak 62 dari 100 responden menjawab setuju berminat wakaf uang dengan persentase dengan minimal melakukan wakaf uang sekali dalam seumur hidupnya bahkan ada yang sampai setahun sekali. Hasil ini terkait dengan $61,1 \%$ responden berpendidikan S1-S3. Hal ini menunjukkan minat yang tinggi terhadap wakaf uang.

2. Variabel religiusitas memiliki pengaruh positif terhadap minat berwakaf uang masyarakat Kota Bandung. Hal ini terkait dengan usia responden yang telah dewasa yang diharapkan dapat mengimplementasikan Wakaf Uang dengan sebaik-baiknya.

3. Variabel pengetahuan tidak memiliki pengaruh positif terhadap minat berwakaf uang masyarakat Kota Bandung. Hal ini terkait dengan latarpendidikan responden yang telah memilki pendidikan yang memadai. Akan tetapi tingkat pendidikan yang tinggi belum tentu mendorong seseorang mengamalkan pengetahuannya dengan baik.

4. Variabel persepsi memiliki pengaruh positif terhadap minat berwakaf uang masyarakat Kota Bandung. Hal ini menunjukkan bahwa minat mayarakat Kota Bandung berwakaf uang dipengaruhi oleh baik buruknya tanggapan masyarakat baik itu kepada wakaf uangnya, maupun lembaga pengelolanya..

5. Variabel pendapatan memiliki pengaruh positif terhadap minat berwakaf uang masyarakat Kota Bandung. Hal ini terkait dengan usia, pekerjaan dan jumlah pendapatan perbulan responden telah mencukup dan diharapkan dapat mendorong untuk berminat Wakaf Uang.

6. Variabel media informasi tidak memiliki pengaruh positif terhadap minat berwakaf uang masyarakat Kota Bandung. Responden masih banyak yang belum mendapatkan 
informasi dari berbagai media, yang mana hanya media sosial di internet responden menerima informasi wakaf uang.

7. Variabel pendapatan dan persepsi merupakan variabel yang dominan mempengaruhi minat wakaf uang masyarakat kota Bandung. Hasil ini ditunjukkan dengan nilai koefisien paling tinggi diantara variabel yang lain yaitu masing-masing sebesar 240 dan 242. Selain itu hasil ini terkait juga dengan usia, pendidikan terakhir, pekerjaan dan jumlah pendapatan responden yang sudah memiliki cukup umur, dengan pendidikan yang layak, dan pekerjaan dan jumlah pendapatan yang memadai mendorong variabel persepsi dan pendapatan menjadi faktor dominan terhadap wakaf uang.

\section{Acknowledge}

Peneliti mengucapan terima kasih kepada para dosen pembimbing Dr. Dewi Rahmi, S.E., M.Si. dan Dr. Hj. Ima Amaliah, S.E., M.Si. yang senantiasa memberikan bimbingan, support dan mendidik penulis sehingga usai nya penulisan skripsi ini, dan juga kepada para responden yang telah bersedia mengisi kuesioner yang telah disebar, juga ucapan terimakasih kepada pihakpihak terkait yang membantu penelitian ini yang tidak bias disebutkan satupersatu.

\section{Daftar Pustaka}

[1] Jalaludin. Psikologi Islam. Jakarta: PT. Raja Grafindo Persada; 2005.

[2] Jamarah dan Aswan Zaini. Strategi Belajar Mengajar. Jakarta: Rineka Cipta; 1996.

[3] Sarlito W. Sarwono. Psikologi Lintas Budaya. Jakarta: rajawali Pers; 2014.

[4] Reskopreyitno. Sistem ekonomi dan Demokrasi Ekonomi. Jakarta: Bina Grafika; 2004.

[5] Sasmita G. Gusti. Rancang Bangun Media. Purwokerto: Universitas Muhammadiyah; 2015.

[6] Khaeriyah. Nahdiyatul. Pengaruh Literasi Terhadap Minat Masyarakat Muslim Berwakaf Uang di Kota Semarang. Semarang: Universitas Islam Negeri Walisongo Semarang; 2019. 